Научная статья

УДК 373.5.016

DOI: $10.18101 / 2307-3330-2021-4-66-69$

\title{
МЕЖДИСЦИПЛИНАРНАЯ ПРОЕКТНАЯ ДЕЯТЕЛЬНОСТЬ В РАМКАХ РАБОТЫ ШКОЛЬНОГО МУЗЕЯ
}

\author{
(C) Кривогорницына Анастасия Васильевна \\ учитель английского языка, \\ Кабанская средняя общеобразовательная школа \\ Россия, 671200, с. Кабанск, ул. 8 Марта \\ a.krivoqornitsyna@gmail.com

\section{(C) Николаева Наталья Сергеевна} \\ учитель истории, \\ Кабанская средняя общеобразовательная школа \\ Россия, 671200, с. Кабанск, ул. 8 Марта \\ dimanikkbnk@gmail.com
}

\begin{abstract}
Аннотация. Данная статья показывает опыт работ работы МАОУ «Кабанская СОШ», раскрывает способы применения метода проектов на примере деятельности школьного музея с применением технологии электронных гуманитарных наук. В рамках междисциплинарного проекта была создана творческая группа, занимающаяся проведением экскурсий на английском и русском языках. Двуязычный контент будет способствовать расширению аудитории канала. Создание такого канала нацелено на сохранение исторической памяти нашего народа и защиту человеческих ценностей, так важных для нашего общества. На базе школы реализуется проект «SLIM» (самый лучший из миров), целью которого является популяризация английского языка через экскурсии по достопримечательностям Кабанска. Особенностью проекта «SLIM» является то, что экскурсии проводят сами учащиеся. Данные экскурсии направлены на популяризацию поисково-краеведческой деятельности, результатом которой является создание информационного канала.

Ключевые слова: проект, школьный музей, экскурсия, электронные гуманитарные науки, междисциплинарный проект, образовательный эффект.
\end{abstract}

\section{Для цитирования}

Кривогорницына А. В. Междисциплинарная проектная деятельность в рамках работы школьного музея // Вестник Бурятского государственного университета. Образование. Личность. Общество. 2021. № 4. С. 66-69.

В современном мире на сегодняшний день ценятся информация, знания, развитый интеллект, креативность человека и созданные на этой основе высокие технологии. Новые ФГОС открывают возможности для реализации данных запросов. Главное стратегическое направление развития системы школьного образования основывается на личностно-ориентированном подходе к обучению. Из всего многообразия педагогических технологий, претендующих на реализацию такого подхода, наиболее актуальным считается метод проектов, не зря индивидуальный проект был введен в старших классах. 
А. В. Кривогорницына. Междисциплинарная проектная деятельность в рамках работы школьного музея

Сегодня популярна идея осуществления инновационной образовательной деятельности на основе сращивания фундаментальных наук и прикладных технологий воплощенная в идее междисциплинарных проектов. Даже было введено новое понятие как «Digital humanities» (электронные гуманитарные науки), которое предполагает тесное переплетение или даже слияние гуманитарных дисциплин и точных наук. «Digital Humanities» - область, которая чрезвычайно интенсивно развивается на западе, но пока что мало представлена в России.

Междисциплинарный проект занимает значительное место в современной организации учебного процесса и является одним из способов, с помощью которого можно подчеркнуть принцип целостности образования и взаимосвязи предметов, изучаемых в школе.

Согласно Федеральному государственному образовательному стандарту, одна из задач учителя - формирование у учащихся метапредметных компетенций. Именно метапредметный подход обеспечивает переход от существующей практики дробления знаний на предметы к целостному образному восприятию мира.

На базе нашей школы уже не первый год реализуется проект «SLIM» (самый лучший из миров), целью которого является популяризация английского языка через экскурсии по достопримечательностям Кабанска. Особенностью проекта «SLIM» является то, что экскурсии проводят сами учащиеся.

В апреле прошлого года наша школа принимала участие в республиканском этапе конкурса школьных музеев, и мы представляли членам жюри экскурсию проекта «SLIM», но на русском языке. Тогда же юные краеведы музея истории Кабанской школы предложили для реализации следующую идею: объединить краеведческую работу с английским языком и ИКТ технологиями. Это предполагает создание YouTube канала, на котором будет размещаться следующий контент: интересные факты из истории школы, рубрика «Они сражались за Родину», культурное наследие Кабанской земли. Информация будет размещаться на 2 языках, что должно популяризировать поисково-краеведческую деятельность. Двуязычный контент будет способствовать расширению аудитории канала. Создание такого канала нацелено на сохранение исторической памяти нашего народа и защиту человеческих ценностей, так важных для нашего общества. Это связано с пропагандой экстремизма, неонацизма и принижением роли советского народа победившего нацистскую Германию.

В проекте задействовано 5 учащихся нашей школы. Они занимаются созданием экскурсий, поиском и сбором информации по истории школы. Полученную информацию, учащиеся переводят на английский язык и снимают видеоролики. Данный видеоматериал найдет свое применение на уроках мужества, классных часах и т. д.

В планах творческой группы создание роликов и размещение их на YouTube канале и странице школьного музея на сайте школы, а также регулярное пополнение экспозиций на портале школьных музеев РФ.

Реализация данного проекта способствует развитию гибких навыков или SOFT SKILLS, а именно развиваются навыки критического мышления, решения задач, публичного выступления, делового общения. Так же ребята учатся работать в команде, организовывать свою деятельность, у них вырабатывается чувство от- 
ветственности и дисциплины. Кроме того, учащиеся познают азы различных профессий: журналист, диктор, оператор, монтажер, сценарист, переводчик. Ребята знакомятся со спецификой работы в музее, архиве. Постигают такие программы как Adobe Photoshop, Adobe InDesign, Movavi Video Editor, In shot.

Интегральные междисциплинарные проекты с широким использованием современных информационных технологий для их выполнения и презентации являются эффективным средством индивидуального сопровождения высоко мотивированных детей, реализации их творческого потенциала.

Таким образом, данная проектная деятельность способствует получению следующего значимого образовательного эффекта. Междисциплинарные проекты помогают учащимся: понять, что многие проблемы можно решить, если рассматривать их с точки зрения разных дисциплин.

Кроме того, междисциплинарная проектная деятельность способствует формированию следующих видов функциональной грамотности: читательская, языковая, компьютерная, информационная. А также развивается общая грамотность, т.е. умение отвечать на вопросы, не испытывая проблемы в построении фраз. Учащиеся свободно излагают свои мысли. Коммуникативная грамотность развивается за счет умений: работать в группе, договариваться, согласовывать свои действия.

Обучение, построенное на межпредметной, интегративной основе способствует повышению уровня мотивации учащихся за счет удовлетворения их разнообразных образовательных интересов, что способствует расширению кругозора и формированию мировоззрения.

В ходе выполнения междисциплинарных проектов формируются не только предметные компетентности по истории, краеведению, географии, английскому языку, информатики, но и происходит формирование всего спектра метапредметных компетентностей обучающихся.

Литература

1. Туманов В. Е. Школьный музей: методическое пособие. 2-е изд., испр. Москва: ЦДЮТиК, 2003. 154 с.

2. Яковлева Н. Ф. Проектная деятельность в образовательном учреждении: учебное пособие. 2-е изд., стер. Москва: ФЛИНТА, 2014. 144 с.

3. Игнатьева Г. А. Проектные формы учебной деятельности обучающихся общеобразовательной школы // Психология обучения. 2013. № 11. С. 20-33.

Статья поступила в редакцию 02.10.2021; одобрена после рецензирования 13.10.2021; принята к публикации 15.12.2021.

\section{SCHOOL MUSEUM AS A MULTIDISCIPLINARY PROJECT ACTIVITY}

Anastasia V. Krivogornitsyna

English teacher

8 March St., Kabansk, 671200 Russia

a.krivoqornitsyna@gmail.com 
А. В. Кривогорницына. Междисциплинарная проектная деятельность в рамках работы школьного музея

\author{
Natalya S. Nikolaeva \\ Teacher of history \\ 8 March St., p. Kabansk, 671200 Russia \\ dimanikkbnk@gmail.com
}

This article shows the experience of the work of Municipal Autonomous Education Institution "Kabanskaya Secondary School", of applying the method of projects on the example of the school museum's activities using electronic humanitarian science technology. As a part of the interdisciplinary project, a group was created, engaged in excursions in English and Russian. Bilingual content will contribute to the extension of the channel audience. The creation of such a channel is aimed at preserving the historical memory of our people and the protection of human values so important for our society. The SLIM (Samyi Luchshiy Iz Mirov) project is being implemented on the basis of the school, the purpose of which is to popularize English through excursions in the sights of Kabansk. The feature of the project is that excursions are held by students themselves. Creating an information channel is the result of the popularization of search and local history activities.

Keywords: project, school museum, excursion, electronic humanities, multidisciplinary project, educational effect.

The article was submitted 02.10.2021; approved after reviewing 13.10.2021; accepted for publication 15.12.2021. 